This is an electronic reprint of the original article. This reprint may differ from the original in pagination and typographic detail.

Author(s): Tokila, Anu; Haapanen, Mika; Ritsilä, Jari

Title: $\quad$ Evaluation of investment subsidies - When is deadweight effect zero?

Year: $\quad 2008$

Version:

Please cite the original version:

Tokila, A., Haapanen, M., \& Ritsilä, J. (2008). Evaluation of investment subsidies When is deadweight effect zero?. International Review of Applied Economics, 22(5), 585-600. https://doi.org/10.1080/02692170802287631

All material supplied via JYX is protected by copyright and other intellectual property rights, and duplication or sale of all or part of any of the repository collections is not permitted, except that material may be duplicated by you for your research use or educational purposes in electronic or print form. You must obtain permission for any other use. Electronic or print copies may not be offered, whether for sale or otherwise to anyone who is not an authorised user. 
Published as: Tokila, A., Haapanen, M. \& Ritsilä, J. (2008) "Evaluation of investment subsidies: when is deadweight zero?", International Review of Applied Economics, 22(5), 585-600.

Forthcoming in International Review of Applied Economics

\title{
Evaluation of Investment Subsidies: When Is Deadweight Zero?
}

\author{
ANU TOKILA, MIKA HAAPANEN AND JARI RITSILÄ \\ School of Business and Economics, University of Jyväskylä
}

16th April 2007

\begin{abstract}
In the evaluation of investment subsidies one of the critical issues concerns the assessment of deadweight, that is, the degree to which projects would have been carried out without grant assistance. With the increasing restrictions on and cuts in subsidies for investment projects in the EU countries maximisation of the impact of the public resources that remain can be achieved through their allocation for projects with minimum deadweight. This paper studies the profile of subsidised zero deadweight investment projects - projects that would be abandoned without public subsidies - in Finland. The empirical analysis is conducted using micro level data on investment projects by private sector firms. The data set comprises 3,423 projects that were granted public investment subsidies between 2001 and 2003. Our results show that the likelihood of zero deadweight is significantly dependent on the characteristics of the subsidised firm, the characteristics of the investment project and the location of the subsidised firm.
\end{abstract}

KEY WORDS:Investment subsidies, deadweight effect, investment projects, public policy, regional policy

JEL CLASSIFICATIONS: H25, R58, D92, C25

Correspondence Address: Anu Tokila, School of Business and Economics, P.O. Box 35, FIN-40014 University of Jyväskylä, Finland. Emails: anu.tokila@econ.jyu.fi, mphaapan@econ.jyu.fi, jari.ritsila@econ.jyu.fi. 


\section{Introduction}

Public business subsidies are a form of financial support given by the state to private sector firms either directly or through intermediary organisations. This support can take the form, for example, of investment aid, small-business aid or aid for development of the business environment. Governments all over the world see such business subsidies as a crucial instrument for boosting new firm formation, generating new ideas and new products, creating employment and decreasing unemployment, and enhancing competitiveness. Also in Finnish entrepreneurship policy, public subsidies have been seen as a key instrument in initiating business projects, especially in distant regions (see e.g. Entrepreneurship Policy Programme, 2005; Regional Development Act, 2002).

EU enlargement to include less developed countries in Central and Eastern Europe has caused a serious shake-up of the EU's financial framework (Council of the European Union, 2006; European Commission, 2004a, 2004b). The so called cohesion policy channels funds to areas and projects that have a maximum impact on competitiveness and growth at the Community level. Simultaneously, the member countries are committed to lowering the ceiling on appropriations. As a result, business subsidies, like many other policy instruments, are reconsidered and reallocated. In particular, investment aid is to be reduced and targeted at the most deserving investment projects. This means that a number of regions and projects currently eligible for subsidies are likely to be denied investment subsidies in the future.

Practically all of the literature on business subsidies has focused solely on the impacts of subsidised projects on the behaviour of firms and on regional growth (e.g. Bergström, 2000; Harris \& Taylor, 2005; Nijkamp \& Blaas, 1995). Before such considerations, however, it is important to study the initial deadweight effect of the 
subsidy. That is, the degree to which the project would have been carried out without grant assistance (Lenihan, 2004; see also Wren, 1996). If the deadweight effect is large, the subsequent changes (e.g. in employment) are irrelevant as they would have been generated without the subsidy. In such cases, the subsidy is a mere transfer payment from tax payer to firm owner. Studies on the deadweight effect of business subsidies have only been occasional so far. However, in her seminal research Lenihan (1999, 2004) studied which projects in Ireland would have gone ahead in the absence of subsidies. In Finland, no detailed analysis on the deadweight effect of business subsidies has so far been conducted.

The purpose of the present paper is to study the conditions under which subsidised investment projects would be abandoned without public assistance (i.e. zero deadweight). ${ }^{1}$ The analysis provides critical information on the importance of investment subsidies for the policy makers who negotiate investment subsidy programmes and for the authorities who grant the subsidies.

Our empirical analysis is conducted using rich data on investment projects by private sector firms in Finland between 2001 and 2003. The data include information, collected before the grant assistance decision, on the characteristics of the subsidised firm and investment project as well as on the location of the subsidised firm, thus allowing us to carry out an ex ante evaluation of the deadweight effect. This is in contrast to the previous ex post studies that have used data collected after the grant has been paid to the firm (e.g. Lenihan, 1999, 2004). ${ }^{2}$

The following section discusses the framework for the analysis of investment subsidies. Our data set, variables and empirical modelling framework are then introduced. In the third section, the estimation results are presented and illustrated. Finally, the conclusion summarises the results and discusses their policy implications. 


\section{Evaluation of investment subsidies}

\subsection{Market failures in the financial markets}

The use of investment subsidies is commonly justified by the existence of market failure in the conventional financial markets (e.g. Storey, 1994; Felsenstein et al., 1998). Because of market failures some firms can be denied access to credit despite the fact that they have viable projects. In particular, investments that are desirable from the standpoint of social welfare might be rejected by private financers. For such investment projects, public assistance might be the only possibility for their implementation.

Information asymmetries may explain why capital does not always flow to firms with profitable investment opportunities (e.g. Stiglitz \& Weiss, 1981). While many essential features of the project are known to the firm, it may not be able credibly to communicate them to outside financiers due to the well-known problems of adverse selection and moral hazard (e.g. Petersen \& Rajan, 1994). In addition to failure of information, public goods, incomplete markets, externalities, failure of competition and macroeconomic disturbances can cause market failures and may provide the rationale for government activity (e.g. Stiglitz, 2000).

The likelihood of market failures and access to finance is dependent on the characteristics of the firm. The prior literature suggest that a firm's access to finance increases with the size and business experience of the firm (e.g. Storey, 1994; Wren, 1998). Young firms do not have much evidence to show regarding their competence and trustworthiness. Small firms are unlikely to be monitored by rating agencies or the financial press. The costs of obtaining information are high in relation to the amount of capital to be supplied (Storey, 1994). Hence, size and age are observable and powerful signals to lenders of investment risk. According recent research by the EU access to 
finance is a major constraint for $20 \%$ of smaller sized firms (European Commission, 2003). In addition, the firm's location frequently matters in determining its risk profile (Felsenstein \& Fleischer, 2002). A distant location may increase the cost of finance and thus create constraints on investment.

There are reasons to believe that project-related factors also affect access to finance and, therefore, the need for public subsidies. As Graham and Harvey (2001) state: 'the project likely has different risk attributes than the overall firm' (p. 232). Therefore, alongside the characteristics of the firm, we must pay attention to risk factors based on the project to be implemented. Evidence for including project characteristics in the risk modelling is also found in Harris (1999), who identifies a set of 12 project risk attributes. The study established that it is not the size of the firm, but rather the relative size of the project, which determines the uncertainty of the outcome.

Just as there can be market failure, so there can be government failure. Government failures can be defined as failures by government to correct a market failure (see e.g. Winston, 2006). Therefore, subsidisation of private sector investments is not unproblematic even in the presence of market failure. The existence of subsidy programmes may, for example, encourage a firm to reduce its own inputs to the investment project. In the worst case, investment assistance entirely substitutes for private funds and generates no increase in the scale of investment and thus implies an arbitrary transfer of resources from tax payer to producer (Wren, 1996). In that event, the firm could have obtained finance in any case and thus public resources are being used needlessly. This particular problem of deadweight is discussed below.

\subsection{Additionality and deadweight}

A key element in the evaluation of any public subsidy instrument is the extent to which the impacts of the project can be attributed to the instrument. The concept of 
'additionality' measures the amount of output from a subsidy instrument compared with what would have occurred without subsidy. Additionality is counterfactually linked to displacement and deadweight. When a subsidy to a firm reduces activity elsewhere in the economy, we are dealing with displacement. Investment subsidies that promote investment activity in certain areas may draw resources from other areas, thus reducing the net impacts of the instrument. ${ }^{3}$

Deadweight - another component of additionality - refers to project outcomes which would have occurred anyway without intervention. The key is to distinguish the changes (intended and unforeseen, positive and negative) which have resulted due to the intervention from those which have not. Some of the effects might have arisen anyway and therefore should not be attributed to the intervention. Deadweight may occur because an intervention is not properly targeted or because the rationale for market failure is faulty. In terms of project implementation, deadweight can be defined as the degree to which projects would have been carried out without grant assistance (Lenihan, 2004).

Lenihan (1999) draws a distinction between degrees of deadweight (see also Lenihan \& Hart, 2004; Wren, 1996). 'Pure (or full) deadweight' indicates that the project would have gone ahead as now unchanged in terms of scale, time and location even in the absence of public financial support. 'Partial deadweight' refers to situations where the project would have gone ahead without financial support, but at a different location, at a later date or on a reduced scale. Deadweight can be minimised by focusing the finance on viable projects that would not be implemented without public aid. 'Zero deadweight' refers to situations in which public subsidy is a prerequisite for project implementation as it would be abandoned in the absence of financial support. Zero deadweight is an optimal starting point for public funding as positive deadweight 
reduces the net impacts, for example, on growth and employment (see e.g. European Commission, 1999c).

Most previous studies (e.g. Lenihan, 1999; Lenihan \& Hart, 2004) have estimated the degree of deadweight and displacement (see also Lenihan et al., 2005). To our knowledge, the likelihood of deadweight for individual firms has been investigated only in Lenihan (2004). In that Irish study it was found that grant type, size of firm, number of earlier grants and whether the investment appraisal included grant had a significant impact on the likelihood of a firm to report deadweight. On the other hand, the amount of the grant received, sector, age of firm, turnover or the amount of the grant as a percentage of turnover proved to be non-significant factors in her logit model.

Deadweight is regarded as a serious indication of inefficiency, and should be addressed in the evaluations of public expenditure programmes within the European Union (European Commission, 1997). Earlier evaluations on EU funding detected a higher degree of deadweight for bigger companies, as they are likely to have access to other sources of funding such as bank loans and requited forms of public support (e.g. European Commission, 1997; see also Wren, 1998). In addition, Heijs (2003) found larger firms to be more often 'freeriders' in terms of public finance for R\&D activities. ${ }^{4}$ The EU evaluations suggest also that in richer regions the danger of deadweight tends to higher, that is, investments would more probably be made even without Community support (see e.g. European Commission, 1997, 2004c).

\section{Data, variables and model}

\subsection{Investment subsidies in Finland}

Although many types of public assistance for business exist in Finland, the investment subsidies administrated by the Ministry of Trade and Industry (KTM) that we are 
concerned with here are all direct grants in that the recipient firm is not obliged to pay back the cash grant to the distributor. In 2003, a total of 1,364 investment projects were subsidised with €66.4 million, which makes investment subsidies the biggest group of business subsidies by the KTM, accounting for $47.1 \%$ of all projects and $60.0 \%$ of all finance (Ministry of Trade and Industry, 2004). In the regions they accounted for 0.1$0.8 \%$ of all private sector investments in 2001-2002 (Ritsilä \& Tokila, 2005). Other forms of non-repayable grants by the KTM are aimed at the development and operating environment of small and medium size enterprises. ${ }^{5}$ Definitions of eligibility for these subsidies are enacted in the Aid to Business Act (1068/2000) and the Decree of Council of State (1200/2000). Primarily the Member States of the European Union cannot themselves assess a firm's eligibility for state aid, but the framework of the rules on the Aid is defined by the European Community Treaty.

The investment subsidies studied here are discretionary, in that a firm's eligibility for grant assistance, and the intensity of assistance is determined by regional authorities rather than tightly specified in legislation. However, in accordance with the law, investment subsidies can be granted to a firm for the purpose of financing fixed assets when the firm is starting up, expanding its operations, or modernising its fixed assets. Investment assistance can be granted for the purchase of machinery and equipment, buildings and land in all businesses, except for those in the farming and fishing sectors. The law provides that assistance can only be given if the intended expansion or modernisation is deemed to lead to major improvements in terms of increasing the number of jobs, adding value to production or enhancing the level of services. An exception to this rule can be made if modernisation essentially upgrades the firm's technology. (Aid to Business Act, 2000; Decree of Council of State, 2000) 
Subsidies for investment are mostly granted by the regional Employment and Economic Development Centres. The KTM only makes the financing decision in cases where the cost of the investment project exceeds $€ 1.7$ million. The European Regional Development Fund (ERDF) participates in the provision of investment subsidies for Objective Areas. (Aid to Business Act, 2000; Decree of Council of State, 2000) In our data set, which is introduced below, $90.4 \%$ of the investment projects received subsidies from the ERDF. On average, about $43 \%$ of this funding came from the ERDF, the remainder coming from national funds.

\subsection{Data set and variables}

The empirical analysis utilises a data set on investment projects by Finnish firms. The unique data set comprises 3,585 investment projects that were initiated and granted investment subsidies between 2001 and $2003 .{ }^{6}$ In the following analysis, we only consider investment projects by private firms. Therefore, public investment projects, together with some observations with missing data, are excluded. This leaves us with 3,423 investment projects. The data set includes a broad range of information not only on the subsidised firm but also on the investment project (see Appendix). Importantly, the data set contains information on the precise assessment made after the firm had submitted its application for project funding.

In the assessment, the investment project and the firm itself are evaluated by researchers at the Employment and Economic Development Centre together with a representative from the applicant firm. The degree of the deadweight effect of the project is estimated by posing the hypothetical question of what will happen if the project is not subsidised. The options in answer to this question are: (1) the project will be abandoned; (2) the project will be implemented on a reduced scale; (3) the project will be implemented on a reduced qualitative level; (4) the project will be implemented 
at a later date; (5) the project will be implemented unchanged. Hence, option (1) implies zero deadweight, options (2)-(4) all imply partial degrees of deadweight and option (5) implies pure deadweight.

In the evaluation of this question, the assessors take into account a wide range of details of the project and the applicant firm. For instance, operation of the firm, content and financial plan of the project, and its need for capital, as well as the financial standing of the applicant firm are reviewed. A more specific method of assessment is used for the most extensive projects, where factors relating to the branch of industry, market structure and development prospects, corporate strategy and success are closely scrutinised. However, no specific criteria for the evaluation of deadweight are established; instead much depends on the assessors themselves. Nevertheless, we argue that this method of assessing deadweight is more reliable than mere self-report by the applicant firm. ${ }^{7}$ Self-reports suffer from intrinsic difficulties, commonly known as the 'respondents effect' or 'response bias' (see e.g. Lenihan, 1999; Lenihan \& Hart, 2004). The applicant firms may deliberately exaggerate, or in some cases underestimate, the importance of assistance for the fear that it may influence present or future public funding. This effect is clearly decreased, when an external evaluator makes the final decision of ex ante deadweight effect.

In this paper, the interest is in determining the conditions under which deadweight is zero. ${ }^{8}$ Therefore, we specify a dummy variable, $y_{i}$, for the analysis as follows:

$$
\begin{aligned}
& y_{i}=1, \text { if the project would have been abandoned in the absence of the } \\
& \text { investment subsidy (i.e. deadweight is zero); } \\
& y_{i}=0 \text {, otherwise. }
\end{aligned}
$$


In explaining the likelihood of zero deadweight, we use variables that describe the characteristics of the subsidised firm and investment project as well as the location of the subsidised firm (see Appendix). The turnover of the firm is measured annually in millions of euros. Its impact on the likelihood of zero deadweight is assumed to be negative due to size factors affecting access to finance, as previously explained (see e.g. Heijs, 2003). The dummy variable of business experience (new firm) indicates whether the firm was recently founded or has been operating for a longer time. A priori one would expect longer experience to diminish the probability of zero deadweight (c.f. Wren, 1998).

The project costs are defined as the purchasing cost of the fixed assets estimated by the applicant firm. Their impact on the probability of zero deadweight is assumed to be positive, since greater costs evidently indicate a higher project risk. In our study, investment-bearing capacity is used to characterise the relative level of project risk. The value of this capacity is calculated by dividing the firm's turnover by the project costs. Therefore, the firm's investment-bearing capacity is positively related to the size of the firm and negatively to the size of the project. Our a priori expectation is that the better the firm's investment-bearing capacity is, the less likely the firm is to need public assistance; for example, it is likely to be able to manage the risks involved in the investment project better and to have access to private funds (see also Harris, 1999).

The value for the relative intensity of assistance is calculated according to the average intensity of assistance in the Assisted Area where the project is implemented (see regional division below). This value is likely to have a positive effect on the project's need for a public subsidy; the higher the intensity of assistance, the more important the role of assistance in the implementation of the investment project. High 
intensity of public assistance may also advance the chances of generating finance from the private sector.

Regional dummies are used to analyse the effects of the location of the subsidised firm on the likelihood of zero deadweight. We have divided Finland into National Assisted Areas using the regional state aid map for Finland ${ }^{9}$ (Figure 1), which shows the regional structure of the Aid to Business Act. This classification is based on the regional level of development and development needs. According to the Treaty establishing the European Community (Article 87), public subsidies are mainly targeted at lagging and peripheral regions.

\section{$<$ FIGURE 1 HERE >}

Projects in National Assisted Area 1 are eligible for the highest intensity of investment aid, which is up to $30 \%$ of the purchasing cost of the fixed assets ${ }^{10}$. It covers the entire Eastern Finland NUTS II area, which is made up of the four NUTS III regions ('maakunnat') of Kainuu, North Karelia, North Savo and South Savo. Projects in National Assisted Area 2 are eligible for a slightly lower maximum intensity of investment assistance (up to $24 \%$ of purchasing cost of the fixed assets). It covers the whole of Lapland and municipalities in North Ostrobothnia, Central Finland and Central Ostrobothnia.

Assisted Areas 1 and 2 have higher unemployment and weaker economic growth rates than the national average. ${ }^{11}$ Their economies depend heavily on the public sector as well as on agriculture and forestry. These two areas are identical to the European Union's Objective 1 Programme Area (i.e. Northern and Eastern Obj. 1). Projects in National Assisted Area 3 are eligible for a significantly smaller maximum level of investment assistance (15\%) than projects in Assisted Areas 1 or 2. The Assisted Area 3 closely resembles the EU's Objective Programme Area 2. Outside the 
National Assisted Areas, only small businesses ${ }^{12}$ are eligible for investment assistance (max. 10\%) and EU funding for structural change areas. Our expectation is that the likelihood of zero deadweight is greater in the peripheral regions (Assisted Area 1 \& 2) as a distant location may weaken opportunities for finance from the private sector (cf. Felsenstein \& Fleischer, 2002).

As in many previous studies, we also control for the timing and industry of the project with dummy variables (see e.g. Bergström, 2000; Harris \& Taylor, 2005). The industry dummies can capture the influence of factors that are common to all projects belonging to the same industry. The year dummies are used to capture cyclical changes in the necessity of investment subsidies and thus in the likelihood of zero deadweight.

\subsection{Descriptive analysis}

Table 1 displays the descriptive statistics by zero deadweight together with simple twosample t-tests. First, note that of the 3,423 investment projects zero deadweight is found for 578 (16.9\% of the projects), that is, the project would have been abandoned in the absence of the investment subsidy. Second, the project costs are significantly higher and the investment-bearing capacity lower in projects with zero deadweight $\left(y_{i}=1\right)$. On the other hand, the t-test shows no significant differences in mean turnover. As discussed above, the relative intensity of assistance compares the intensity of assistance in a specific project with the average intensity of assistance in the region where the project is implemented. The t-test shows no significant differences in its means in the samples of $y_{i}=0$ and $y_{i}=1$.

\section{< TABLE 1 HERE >}

The descriptive analysis suggests that the deadweight effect of the investment subsidy does not seem to vary with the relative intensity of assistance. To test whether 
this and the other descriptive findings hold after other factors have been controlled for requires estimation of our econometric model; see equations (1) and (2) below. Since the intensity of assistance is highly dependent on the region where investment project is implemented, we cannot include both the regional dummies and the intensity of assistance in our econometric model. Instead, we use the relative intensity of assistance as an explanatory variable together with the regional dummies. These variables allow us to study whether the deadweight effect of the subsidy depends on the intensity of assistance after controlling for the location of the project.

\subsection{Modelling framework}

The construction of the dependent variable, $y_{i}$, as binary suggests the use of a probit (or logit) model (see e.g. Greene, 2003). Thus, we assume that zero deadweight, $y_{i}$, is determined according to a latent variable $y_{i}^{*}$ :

$$
\begin{aligned}
& y_{i}^{*}=\beta^{\prime} x_{i}+\varepsilon_{i}, \quad \varepsilon_{i}=N\left(0, \sigma_{i}^{2}\right) \\
& y_{i}=1, \text { if } y_{i}^{*}>0 ; \text { and } y_{i}=0, \text { if } y_{i}^{*} \leq 0,
\end{aligned}
$$

where $x_{i}$ is a vector of the explanatory variables and $\beta$ is a parameter vector. The variance of the error term $\varepsilon_{i}$ is allowed to depend on a set of explanatory variables, $z_{i}$ (see e.g. Davidson \& MacKinnon, 1984):

$$
\sigma_{i}^{2}=\left[\exp \left(\gamma^{\prime} z_{i}\right)\right]^{2}
$$

where $\gamma$ is an additional parameter vector to be estimated with $\beta$. This multiplicative heteroskedasticity is introduced into the model, because uncorrected departures from homoskedasticity can bias the estimated parameters and standard errors in non-linear models (Godfrey, 1988). Note that a homoskedastic probit model can be estimated by setting the variance of the error term to one $\left(\sigma_{i}^{2}=1\right)$. Thus, the presence of 
heteroskedasticity can be tested easily, for example, with Likelihood Ratio (LR) tests (Greene, 2003).

\section{Results}

Table 2 displays the estimation results of our probit models for zero deadweight. Before interpretation, the validity of the results is scrutinised by comparing three different probit model specifications. The comparisons are made with a number of diagnostic test results; these are given at the bottom of the table. ${ }^{13}$

First, a homoskedastic model specification (1) is given. Looking at the diagnostic results, we can see that the Likelihood Ratio (LR) test statistic for heteroskedasticity is highly significant, so that the null hypothesis of homoskedasticity is rejected. This test compares specification (1) to (2), where the variance of the error term is allowed to depend on the $\ln$ (project costs) and the turnover of the firm. ${ }^{14}$ The validity of our model specifications is also investigated with normality tests. We find that the normality assumption of the error term is rejected in specification (1): the Conditional Moment (CM) test rejects the null hypothesis of normality at the 5 percent level. ${ }^{15}$ In contrast, the normality of the error term is not rejected in specification (2). Thus, model specification (2) is clearly preferred to (1).

\section{$<$ TABLE 2 HERE >}

Given that the turnover of firm does not have a significant direct affect on the likelihood of zero deadweight in specification (2), we examined whether it could be dropped from the explanatory variables; see specification (3). The LR test for the omitted variable - i.e. comparison of specifications (2) and (3) - implies that the turnover of firm should be included in the explanatory variables. Hence, we conclude that the second model specification is the most parsimonious. The estimated parameters 
hardly differ between the two model specifications, implying stability of our results. ${ }^{16}$ In the preferred model specification (2), all the reported coefficients reach statistical significance at the 5 percent risk level, except for the dummy variable Assisted Area 3 and the turnover of the firm.

As regards the signs of the parameter estimates, a variable with a positive (negative) coefficient is associated with an increased (decreased) probability of zero deadweight and thus a decreased (increased) probability of deadweight. In accordance with our expectations and consistent with Wren (1998) the results show that the likelihood of zero deadweight is significantly smaller for new firms than for old. Thus, the investment project is more likely to be abandoned in the absence of the subsidy in new firms. This result is in contrast with Lenihan (2004), in which the age of a firm has a non-significant, positive effect on the deadweight.

As expected, the size of deadweight is also estimated to be significantly smaller the higher the project costs, ceteris paribus. The project costs are included in logarithmic form to capture non-linearity in their effect on deadweight. A unit increase in the projects costs has larger effect on the likelihood of zero deadweight when the costs are smaller (see also illustration below). However, we reject our initial expectation that turnover itself has negative effect on the likelihood of zero deadweight. Instead, we find that investment-bearing capacity, defined as the ratio of turnover to projects costs, determines the deadweight effect of the investment subsidy. This supports the findings of Harris (1999) that it is the relative size of the project rather than the size of the firm that increases the project risk.

Continuing with the regional variables, the results support Felsenstein and Fleischer (2002) and the European Commission (1997, 2004c). As expected, the likelihood of zero deadweight is higher in the lagging and peripheral regions. The 
investment subsidy is more crucial for projects in Assisted Areas 1 and 2, located in Eastern and Northern Finland, than for projects outside Assisted Areas (the reference region located in the Southern and Western Finland). No significant differences are found between Assisted Area 3 (Central Finland) and the reference region. Further on, the results lend support to our hypothesis that the higher the relative intensity of assistance when compared to other projects in the region, the greater the likelihood of zero deadweight is. ${ }^{17}$ As a whole, these regional findings suggest that the concentration of public assistance to peripheral regions seems to be justified.

Six industry dummies, together with year dummies, were used as control variables (see also Appendix). Interestingly, our findings show that deadweight is dependent on industry even after controlling for other factors. The industry dummy variables suggest that deadweight is smallest for projects in wood manufacturing (including furniture), and in transport, storage, communication and financial intermediation. Although, there are no strong a priori reasons for these differences, one possible explanation is that the wood and transportation industries are capital intensive and have traditionally been supported by the state (see e.g. Teuvo, 1998).

In order to obtain an overview of the size of the effects, conditional predicted probabilities of zero deadweight were computed for selected hypothetical cases using the preferred model specification (2); see Table 3. The predicted probabilities are provided, because it is difficult to see the magnitude of the effects from the parameter estimates when the error variance is a function of the explanatory variables (presence of heteroskedasticity) and/or the explanatory variable is in logarithmic form. In each case the other explanatory variables are held at their median values; for the median values see the notes to the table. ${ }^{18}$

\section{$<$ TABLE 3 HERE >}


The predicted probability is first given as a function of project costs (Case 1). Assuming that the other variables are held at their median values, except for investmentbearing capacity, which is allowed to change accordingly, an increase in the project costs for instance by $€ 400,000$, from $€ 100,000$ to $€ 500,000$, would raise the probability of zero deadweight by approximately 3 percentage points. Whereas a change in the project costs from $€ 100,000$ to $€ 1$ million increases the probability of zero deadweight by almost 6 percentage points. Similarly, Case 2 shows that an increase from 5 to 10 in investment-bearing capacity (e.g. doubling turnover while project costs remain unchanged) would reduce the probability of zero deadweight by approximately 1 percentage point. $^{19}$

Zero deadweight is more strongly dependent on the location of the project and relative intensity of assistance (Case 3 and 4). The probability of zero deadweight is over three times larger for investment projects in Assisted Area 1 and over two times greater in Assisted Area 2 than for projects outside the Assisted Areas. On the other hand, if the project's intensity of assistance is twice the regional average, then the probability of zero deadweight is more than two times greater (i.e. comparing the relative intensities of 1 and 2). Hence, it seems that the deadweight of an investment subsidy depends on the intensity of assistance even after controlling for the location of the project.

\section{Conclusion}

Given that public funding and opportunities for subsidising investments are likely to decrease in the future, it is important to consider what would most likely happen to projects in the absence of public funding. If there are deadweight effects in an assisted project, some (or even all) of the planned/desired economic activity would have 
happened anyway in the absence of the intervention. Therefore, to maximise the added value of public finance, the primary focus should be on projects for which investment subsidies have no deadweight effect. Our empirical analysis has provided some important prospects for policy makers in this respect. Besides programme planning, the results may be useful in the development of more specific indicators for evaluating the deadweight of projects applying for subsidies.

The analysis has clearly shown that, at least in Finland the likelihood of investment subsidies having zero deadweight varies significantly between investment projects with different characteristics. The likelihood that the deadweight effect of an investment subsidy is zero is greater for projects in distant regions (i.e. in Northern and Eastern Finland) than in central areas (i.e. in Southern Finland). Our interpretation is that these regional differences are partly due to differences in need for public assistance and partly due to differences in the intensity of assistance. We also find that the investment-bearing capacity of the firm, defined as the ratio of turnover to project costs, determines the deadweight effect of the investment subsidy rather than the mere size of the firm. Moreover, our results show that the deadweight of the investment subsidy is smaller for new firms than for old, and that it diminishes with the size of the investment project. These results can be linked to access to finance, as lower investment-bearing capacity and less business experience on part of the firm and a smaller size of project may be signals of higher risk. Our findings are thus consistent with the prior literature on access to finance and reasons for deadweight.

It should be taken into account that the impact of a subsidy on the implementation of a project is only the first condition for the subsidy. After this, other implications that investment subsidies might have for economic activity can be studied. For example, do investment subsidies promote growth of business or employment, or do 
they generate an increase in the private funding of investment projects? In addition, comparison of ex ante analysis with ex post information could provide valuable information on appraising the deadweight effect of a project.

\section{Acknowledgement}

We gratefully acknowledge funding from the Yrjö Jahnsson Foundation (projects 4977 and 5204). Anu Tokila also wishes to thank the Academy of Finland for financial support (project 200856). The authors would like to thank Mikko Mäkinen, Francois Pouget, Hannu Tervo, Petri Böckerman and Boris A. Portnov for their valuable comments on this paper.

\section{$<$ APPENDIX TABLE AROUND HERE >}

\section{References}

Aid to Business Act (1068/2000) in Ministry of Justice (2006) Finnish Law I.

Bergström, F. (2000) Capital subsidies and the performance of firms, Small Business Economics, 14, pp. 183-193.

Council of the European Union (2006) Council Decision of 6 October 2006 on Community strategic guidelines on cohesion (2006/702/EC), Official Journal of the European Union, L 291/11.

Davidson, R. \& MacKinnon, J. G. (1984) Convenient specification tests for logit and probit models, Journal of Econometrics, 25, pp. 241-262.

Decree of Council of State (1200/2000) in Ministry of Justice (2000) The Statutes of Finland.

Entrepreneurship Policy Programme (2005) in The Prime Minister's Office (2005) Government policy programmes. 
European Commission (1997) Evaluation EU Expenditure Programmes: A Guide, Ex Post and Intermediate Evaluation, Budgetary Overview and Evaluation XIX/02, Directorate General - Budgets.

European Commission (1999a) Evaluating Socio-Economic Programmes: Evaluation Design and Management, MEANS Collection 1, EC Structural Funds (Luxembourg, Office for Official Publications of the European Communities).

European Commission (1999b) Evaluating Socio-Economic Programmes: Principal Evaluation Techniques and Tools, MEANS Collection 3, EC Structural Funds (Luxembourg, Office for Official Publications of the European Communities).

European Commission (1999c) Evaluating Socio-Economic Programmes: Transversal Evaluation of Impacts on the Environment, Employment and Other Intervention Priorities, MEANS Collection 5, EC Structural Funds (Luxembourg, Office for Official Publications of the European Communities).

European Commission (1999d) Evaluating Socio-Economic Programmes: Glossary of 300 concepts and technical terms, MEANS Collection 6, EC Structural Funds (Luxembourg, Office for Official Publications of the European Communities).

European Commission (2003) Microcredit for Small Businesses and Business Creation: Bridging a Market Gap (Enterprise publications).

European Commission (2004a) Communication from the Commission to the Council and the European Parliament: Financial perspectives 2007-2013, COM (2004) 487. European Commission (2004b) Communication from the Commission to the Council and the European Parliament: Building our common Future Policy challenges and Budgetary means of the Enlarged Union 2007-2013, COM (2004) 101. 
European Commission (2004c) Annual evaluation review 2003: Overview of the Commission's evaluation activities and main evaluation findings, DirectorateGeneral for the Budget, SEC (2004) 662.

Felsenstein, D. \& Fleischer, A. (2002) Small-scale entrepreneurship and access to capital in peripheral locations: an empirical analysis, Growth and Change, 33, pp. $196-215$.

Felsenstein, D., Fleischer, A. \& Sidi, A. (1998) Market failure and the estimation of subsidy size in a regional entrepreneurship programme, Entrepreneurship \& Regional Development, 10, pp. 151-165.

Godfrey, L. G. (1988) Misspecification Tests in Econometrics: The Lagrange Multiplier and Other Approaches (Cambridge, Cambridge University Press).

Graham, J. R. \& Harvey, C. R. (2001) The theory and practice of corporate finance: evidence from the field, Journal of Financial Economics, 60, pp. 187-243.

Greene, W. H. (2003) Econometric Analysis, 5th edn (New Jersey, Prentice-Hall).

Harris, E. (1999) Project risk assessment: a European field study, British Accounting Review, 31, pp. 347-371.

Harris, R. \& Taylor, M. (2005) Capital subsidies and their impact on total factor productivity: firm-level evidence from Ireland, Journal of Regional Studies, 45, pp. $49-74$.

Heijs, J. (2003) Freerider behaviour and the public finance of R\&D activities in enterprises: the case of the Spanish low interest credits for R\&D, Research Policy, 32, pp. 445-461.

Lenihan, H. (1999) An evaluation of a regional development agency's grants in terms of deadweight and displacement, Environment and Planning $C$ : Government and Policy, 17, pp. 303-318. 
Lenihan, H. (2004) Evaluating Irish industrial policy in terms of deadweight and displacement: a quantitative methodological approach, Applied Economics, 36, pp. $229-252$.

Lenihan, H. \& Hart, M. (2004) The use of counterfactual scenarios as a means to assess policy deadweight: an Irish case study, Environment and Planning C: Government and Policy, 22, pp. 817-839.

Lenihan, H., Hart, M. \& Roper, S. (2005) Developing an evaluative framework for industrial policy in Ireland: fulfilling the audit trail or an aid to policy development, in: Quarterly Economic Commentary Summer 2005, pp. 69-85 (Economic and Social Research Institute).

Ministry of Finance (2005) Economic survey, February 2005, Economic and Economic Policy Surveys 1b/2005.

Ministry of Finance (2006a) Economic survey, February 2006, Economic and Economic Policy Surveys 1b/2006.

Ministry of Finance (2006b) Employment determination, job creation and destruction in the present economic cycle in Finland, Economics report 3/2006.

Ministry of Trade and Industry (2004) Annual Report 2003, Annual Reports of Ministry of Trade and Industry.

Newey, W. K. (1985) Maximum likelihood specification testing and conditional moment tests, Econometrica, 53, pp. 1047-1070.

Nijkamp, P. \& Blaas, E. (1995) Comparative regional policy impact analysis: ex post evaluation of the performance of the European Regional Development Fund, Journal of Regional Science, 35, pp. 579-597.

Petersen, M. A. \& Rajan, R. G. (1994) The benefits of lending relationships: evidence from small business data, Journal of Finance, 49, pp. 3-37. 
Regional Development Act (602/2002) in Ministry of Justice (2006) Finnish Law I.

Ritsilä, J. \& Tokila, A. (2005) Evaluation of the effectiveness and functioning of the aid scheme under the Aid to Business Act 1068/2000 (in Finnish), Publications of Ministry of Trade and Industry 21/2005.

Roper, S. \& Hewitt-Dundas, N. (2001) Grant assistance and small firm development in Northern Ireland and the Republic of Ireland, Scottish Journal of Political Economy, 48, pp. 99-117.

Stiglitz, J. E. (2000) Economics of the Public Sector, 3rd edn (London, Norton).

Stiglitz, J. E. \& Weiss, A. (1981) Credit rationing in markets with imperfect information, American Economic Review, 71, pp. 393-410.

Storey, D. J. (1994) Understanding the Small Business Sector (London, Routledge).

Tervo, H. (1989) A micro-level approach to the analysis of the displacement effects of regional incentive policy: the case of Finland, Regional Studies, 23, pp. 511-521.

Tervo, H. (1990) Factors underlying displacement: an analysis of Finnish regional incentive policy using survey data on assisted firms, Applied Economics, 22, pp. $617-628$.

Teuvo, J. (1998) Trends in the public support to industries in 1984-1996 (in Finnish), Government Institute for Economic Research, Discussion Paper No. 165.

Winston, C. (2006) Government Failure vs. Market Failure: Microeconomics Policy Research and Government Performance (Washington, AEI-Brookings Joint Center).

Wren, C. (1996) Fund substitution and the incentive effects of public investment subsidies, Scottish Journal of Political Economy, 43, pp. 534-548.

Wren, C. (1998) Subsidies for job creation: is small best?, Small Business Economics, 10, pp. 273-281. 


\section{Notes}

1. We concentrate on zero deadweight projects only, since their net impacts are more straightforward compared to partial deadweight projects despite the fact that zero deadweight projects also include the possibility of displacement effects.

2. These two stages of evaluation are linked together (see e.g. European Commission 1999a, 1999b, 1999c). Ex ante evaluation helps to ensure that the subsidised projects are in accordance with the objectives of the programme. Ex post evaluation recapitulates and judges an intervention when it is over.

3. For more on displacement, see e.g. Tervo $(1989,1990)$ and Lenihan (1999).

4. Note the term 'freerider' in Heijs (2003) can be referred as deadweight.

5. Besides non-repayable cash grants, the Ministry of Trade and Industry also supports business by loans, guarantees and export finance.

6. Finland's post-war economic development was based on intensive investment and the import of foreign capital (Ministry of Finance, 2005). In the 1960s and 1970s the investment rate, i.e. investment as a proportion of total output, was extremely high, occasionally exceeding $30 \%$. The investment rate fell during the deep recession of the early 1990s. After reaching its lowest, $15.5 \%$ in 1994, investment began to recover, peaking at $20.5 \%$ in 2001 . Since, it has fallen slightly to around $18-19 \%$ during 2002 2006 (Ministry of Finance, 2006a).

7. Alternatively, one could have tried to evaluate deadweight by using control groups that allow controlling for selectivity bias (see e.g. Roper \& Hewitt-Dundas, 2001). However, we are unable to construct a suitable group of investment projects, as it is 
very difficult to access data on non-assisted investment projects in Finland. See Lenihan and Hart (2004), and references therein, for a general discussion of alternative approaches in evaluating the impact of government policies.

8. We only consider the option of zero deadweight, as the options of partial deadweight (2)-(4) are much harder to quantify by size.

9. Based on Letters to the Member States, Regional Aid Map 2000-2006, SG(99) D/10189.

10. The maximum amounts of aid for each Assisted Area are directive and can be exceeded depending on the character and the significance of the project.

11. The Finnish economy experienced a very deep recession in the early 1990s. From the mid-1990s, after joining the European Union and adopting the euro currency, Finland's economic growth took an upward turn, with a GDP growth of 3-6\% in 19952000. The growth rate fell to $2 \%$ in $2001-2002$, but it has accelerated since (see e.g. Ministry of Finance, 2006b).

12. According to the Decree of Council of State (1200/2000), a small business is defined as a firm with personnel not exceeding 50 employees and with either an annual turnover of a maximum of $€ 7$ million or a balance sheet total of a maximum of $€ 5$ million.

13. Since our specification of the error variance in model (1) is different from that in models (2) or (3), a direct comparison of parameter estimates is not advisable. 14. Note that the form of heteroskedasticity is not rejected in specification (2) and (3) when tested against a more general form of heteroskedasticity (see diagnostics in Table 2). The test for the more general heteroskedasticity compares the model with a model 
that includes all the independent variables save the constant term, industry and year dummies in the heteroskedastic function.

15. The CM test for the normality of the error term is implemented as described in Newey (1985, p. 1062).

16. We also tried to add the turnover of the firm in a second polynomial form to study whether the impact of turnover is dependent on its level. Since it was not significant at the 5 percent level, it was concluded that the impact of turnover on zero deadweight does not vary with the level of turnover.

17. We also tried various other regional variables, including the level of urbanisation, provincial centre dummies and the firm's distance from the provincial centre, but they did not prove to be significant determinants.

18. In our data the range of project costs, turnover of the firm and relative intensity of assistance are [832, 20 million], [0, 118.7 million] and [0.192, 2.427], respectively. The mean values of the variables are given in the Appendix.

19. Since the illustration assumes that the project costs are same (€92,503), the difference in the investment-bearing capacities (5 versus 10) means that the annual turnover is $€ 462,515$ in the former firm and $€ 925,030$ in the latter firm. 


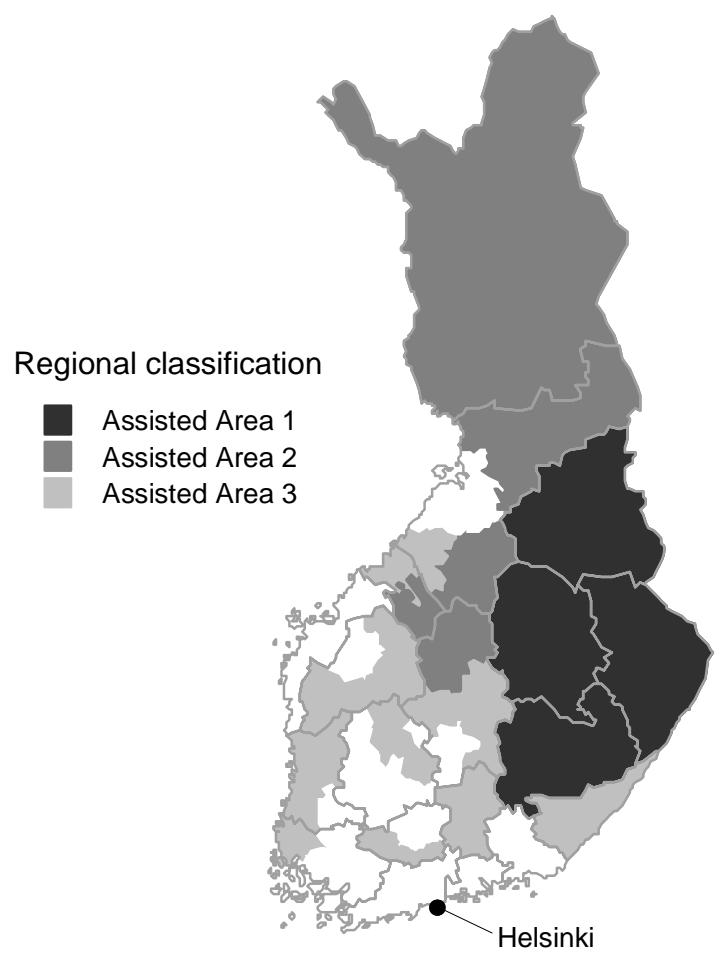

Figure 1. National Assisted Areas in Finland (with borders of NUTS III regions) 
Appendix. Definitions of variables and their mean values

\begin{tabular}{|c|c|c|}
\hline Variable & Definition & Mean \\
\hline Zero deadweight $\left(y_{i}\right)$ & $\begin{array}{l}1 \text { if the project would have been abandoned in the absence } \\
\text { of the investment subsidy (i.e. deadweight is zero); } 0 \\
\text { otherwise. }\end{array}$ & 0.169 \\
\hline Turnover of firm & Annual turnover of firm ( $€$ millions). & 1.635 \\
\hline New firm & $\begin{array}{l}1 \text { if the investment project is implemented by new firm } \\
\text { (definition by Statistics Finland); } 0 \text { otherwise. }\end{array}$ & 0.238 \\
\hline Project costs & $\begin{array}{l}\text { Total project costs (i.e. purchasing cost of the fixed assets) } \\
\text { as estimated by the firm in its investment subsidy } \\
\text { application ( } € \text { millions). }\end{array}$ & 0.290 \\
\hline $\begin{array}{l}\text { Investment-bearing } \\
\text { capacity }\end{array}$ & Turnover of firm divided by project costs. & 9.711 \\
\hline $\begin{array}{l}\text { Relative intensity of } \\
\text { assistance }\end{array}$ & $\begin{array}{l}\text { Intensity of assistance divided by the average intensity of } \\
\text { assistance in the Assisted Area where the project is } \\
\text { implemented. Intensity of assistance is calculated as a } \\
\text { ratio of investment subsidy to the total project costs. }\end{array}$ & 1 \\
\hline \multicolumn{3}{|l|}{ Regional dummies } \\
\hline Assisted Area 1 & $\begin{array}{l}1 \text { if the project is implemented in the National Assisted } \\
\text { Area } 1 ; 0 \text { otherwise; see Figure } 1 .\end{array}$ & 0.222 \\
\hline Assisted Area 2 & $\begin{array}{l}1 \text { if the project is implemented in the National Assisted } \\
\text { Area 2; } 0 \text { otherwise. }\end{array}$ & 0.190 \\
\hline Assisted Area 3 & $\begin{array}{l}1 \text { if the project is implemented in the National Assisted } \\
\text { Area } 3 ; 0 \text { otherwise. }\end{array}$ & 0.361 \\
\hline Other regions & $\begin{array}{l}1 \text { if the project is implemented outside the National } \\
\text { Assisted Areas 1-3; } 0 \text { otherwise. Reference region. }\end{array}$ & 0.228 \\
\hline \multicolumn{3}{|l|}{ Industry dummies } \\
\hline Metal & $\begin{array}{l}1 \text { if the project is manufacturing of fabricated metal } \\
\text { products; } 0 \text { otherwise. }\end{array}$ & 0.268 \\
\hline Wood & $\begin{array}{l}1 \text { if the project is manufacturing of wood and of products } \\
\text { of wood and cork, including furniture, or of articles of } \\
\text { straw and plaiting materials; } 0 \text { otherwise. }\end{array}$ & 0.157 \\
\hline Other manufacturing & $\begin{array}{l}1 \text { if the project is in another manufacturing industry; } 0 \\
\text { otherwise. }\end{array}$ & 0.234 \\
\hline Trade & $\begin{array}{l}1 \text { if the project is in wholesale and retail trade, repair of } \\
\text { motor vehicles, motorcycles and personal and household } \\
\text { goods, or hotels and restaurants; } 0 \text { otherwise. }\end{array}$ & 0.091 \\
\hline Transport & $\begin{array}{l}1 \text { if the project is in transport, storage and communication, } \\
\text { or financial intermediation; } 0 \text { otherwise. }\end{array}$ & 0.024 \\
\hline Business & $\begin{array}{l}1 \text { if the project is in real estate, renting and business } \\
\text { activities; } 0 \text { otherwise. Reference industry. }\end{array}$ & 0.132 \\
\hline Other industries & 1 if the project is in another industry; 0 otherwise. & 0.094 \\
\hline
\end{tabular}


Table 1. Descriptive statistics by zero deadweight $\left(y_{i}\right)$

\begin{tabular}{|c|c|c|c|c|}
\hline \multirow[b]{2}{*}{ Variable } & \multicolumn{2}{|c|}{ Mean by $y_{i}$ (std. dev.) } & \multirow{2}{*}{$\begin{array}{l}\text { Overall mean } \\
\quad(\text { std. dev) }\end{array}$} & \multirow{2}{*}{ t-test } \\
\hline & $y_{i}=0$ & $y_{i}=1$ & & \\
\hline $\begin{array}{l}\text { Project costs } \\
(€ \text { millions })\end{array}$ & $0.249(0.614)$ & $0.493(1.483)$ & $0.290(0.832)$ & $-3.889 *$ \\
\hline $\begin{array}{l}\text { Turnover of firm } \\
(€ \text { millions })\end{array}$ & $1.528(4.274)$ & $2.159(8.496)$ & $1.635(5.235)$ & -1.742 \\
\hline $\begin{array}{l}\text { Investment- } \\
\text { bearing capacity }\end{array}$ & $10.392(32.720)$ & $6.362(11.205)$ & $9.711 \quad(30.219)$ & $5.239 *$ \\
\hline $\begin{array}{l}\text { Relative intensity } \\
\text { of assistance }\end{array}$ & $0.997(0.169)$ & $1.013(0.184)$ & $1.000(0.172)$ & -1.899 \\
\hline $\begin{array}{l}\text { Number of } \\
\text { projects }\end{array}$ & 2,845 & 578 & 3,423 & 3,423 \\
\hline
\end{tabular}


Table 2. Parameter estimates of the probit models

\begin{tabular}{|c|c|c|c|c|c|c|}
\hline \multirow{2}{*}{ Variable } & \multicolumn{6}{|c|}{ Model specification } \\
\hline & \multicolumn{2}{|c|}{ (1) } & \multicolumn{2}{|c|}{ (2) } & \multicolumn{2}{|c|}{ (3) } \\
\hline Constant & $-1.666^{* *}$ & $(0.197)$ & $-2.202 * *$ & $(0.333)$ & $-2.239 * *$ & $(0.318)$ \\
\hline Turnover of firm & 0.008 & $(0.005)$ & -0.066 & $(0.034)$ & - & \\
\hline New firm & $0.193 * *$ & $(0.067)$ & $0.234^{*}$ & $(0.111)$ & $0.251^{*}$ & $(0.104)$ \\
\hline $\ln$ (project costs) & $0.093 * *$ & $(0.021)$ & $0.436 * *$ & $(0.067)$ & $0.363 * *$ & $(0.060)$ \\
\hline $\begin{array}{l}\text { Investment-bearing } \\
\text { capacity }\end{array}$ & $-0.007 * *$ & $(0.003)$ & $-0.022 * *$ & $(0.007)$ & $-0.020 * *$ & $(0.008)$ \\
\hline $\begin{array}{l}\text { Relative intensity of } \\
\text { assistance }\end{array}$ & $0.444 * *$ & $(0.155)$ & $0.754 * *$ & $(0.253)$ & $0.751 * *$ & $(0.238)$ \\
\hline \multicolumn{7}{|l|}{ Regional dummies } \\
\hline Assisted Area 1 & $0.702 * *$ & $(0.080)$ & $1.141 * *$ & $(0.142)$ & $1.060 * *$ & $(0.137)$ \\
\hline Assisted Area 2 & $0.455 * *$ & $(0.086)$ & $0.787 * *$ & $(0.147)$ & $0.721 * *$ & $(0.140)$ \\
\hline Assisted Area 3 & 0.149 & $(0.078)$ & 0.245 & $(0.127)$ & 0.228 & $(0.119)$ \\
\hline \multicolumn{7}{|l|}{ Industry dummies } \\
\hline Metal & 0.010 & $(0.097)$ & 0.203 & $(0.173)$ & 0.161 & $(0.163)$ \\
\hline Wood & 0.138 & $(0.102)$ & $0.370^{*}$ & $(0.182)$ & 0.322 & $(0.171)$ \\
\hline Other manufacturing & 0.131 & $(0.096)$ & 0.325 & $(0.173)$ & 0.270 & $(0.163)$ \\
\hline Trade & 0.107 & $(0.116)$ & 0.192 & $(0.194)$ & 0.203 & $(0.184)$ \\
\hline Transport & 0.334 & $(0.172)$ & $0.681^{*}$ & $(0.296)$ & $0.627 *$ & $(0.281)$ \\
\hline Other industries & 0.055 & $(0.114)$ & 0.240 & $(0.205)$ & 0.211 & $(0.194)$ \\
\hline Year dummies (2) & \multicolumn{2}{|c|}{ Yes } & \multicolumn{2}{|c|}{ Yes } & \multicolumn{2}{|c|}{ Yes } \\
\hline \multicolumn{7}{|c|}{ Correction for heteroskedasticity } \\
\hline \multicolumn{3}{|l|}{$\ln$ (project costs) } & $-0.204 * *$ & $(0.029)$ & $-0.186^{* *}$ & $(0.032)$ \\
\hline Turnover of firm & \multicolumn{2}{|l|}{-} & $0.050 * *$ & $(0.016)$ & 0.023 & $(0.014)$ \\
\hline \multicolumn{7}{|l|}{ Diagnostics } \\
\hline \multicolumn{3}{|l|}{ Log-likelihood } & $-1,44^{\prime}$ & 7.80 & $-1,450$ & 91 \\
\hline LR test for heterosked. & $29.43 * *(c$ & d.f. $=2)$ & - & & - & \\
\hline $\begin{array}{l}\text { LR test for more general } \\
\text { heteroskedasticity }\end{array}$ & - & & $6.58(d$ & $. f .=6)$ & $9.01(\mathrm{~d}$. & $f=6)$ \\
\hline CM test for normality & $10.91 *(d$ & l.f. $=2)$ & $3.95(d$ & $. f .=2)$ & $2.39(\mathrm{~d} .1$ & $f=2)$ \\
\hline $\begin{array}{l}\text { LR test for omitted } \\
\text { variable }\end{array}$ & - & & 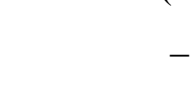 & & $6.21 *(\mathrm{~d}$ & $f .=1)$ \\
\hline
\end{tabular}


Table 3. Illustration with predicted probabilities, $\operatorname{Prob}\left(y_{i}=1\right)$

Predicted probability conditional on other variables are held at median values

\begin{tabular}{|c|c|c|c|}
\hline \multicolumn{4}{|c|}{ Case 1: Project costs } \\
\hline $\begin{array}{l}\text { Project costs are } \\
\quad € 10,000\end{array}$ & $\begin{array}{l}\text { Project costs are } \\
€ 100,000\end{array}$ & $\begin{array}{l}\text { Project costs are } \\
\quad € 500,000\end{array}$ & $\begin{array}{l}\text { Project costs are } \\
€ 1 \text { million }\end{array}$ \\
\hline 0.069 & 0.097 & 0.125 & 0.154 \\
\hline \multicolumn{4}{|c|}{ Case 2: Investment-bearing capacity } \\
\hline $\begin{array}{l}\text { Investment-bearing } \\
\text { capacity is } 0\end{array}$ & $\begin{array}{l}\text { Investment-bearing } \\
\text { capacity is } 5\end{array}$ & $\begin{array}{l}\text { Investment-bearing } \\
\text { capacity is } 10\end{array}$ & $\begin{array}{l}\text { Investment-bearing } \\
\text { capacity is } 50\end{array}$ \\
\hline 0.104 & 0.095 & 0.086 & 0.047 \\
\hline \multicolumn{4}{|c|}{ Case 3: Location of project } \\
\hline Assisted Area 1 & Assisted Area 2 & Assisted Area 3 & Other regions \\
\hline 0.223 & 0.165 & 0.096 & 0.073 \\
\hline \multicolumn{4}{|c|}{ Case 4: Relative intensity of assistance } \\
\hline $\begin{array}{l}\text { Relative intensity is } \\
0.5\end{array}$ & $\begin{array}{c}\text { Relative intensity is } \\
1\end{array}$ & $\begin{array}{c}\text { Relative intensity is } \\
1.5\end{array}$ & $\begin{array}{l}\text { Relative intensity is } \\
2\end{array}$ \\
\hline 0.063 & 0.097 & 0.142 & 0.199 \\
\hline \multicolumn{4}{|c|}{$\begin{array}{l}\text { The probabilities have been calculated using model specification (2) in Table } 2 \text {. Median value } \\
\text { are the following: project cost } € 92,503 \text {, turnover of firm } € 380,000 \text {, investment-bearing capacit } \\
4.072 \text {, project is manufacturing of fabricated metal products in Assisted Area } 3 \text {, funding } \\
\text { granted to operating (i.e. non-new) firm in } 2001 \text {, and the relative intensity of assistance is } 0.955 \\
\text { Definitions of variables are given in the Appendix. Changes in project costs cause diversity i } \\
\text { investment-bearing capacity. Likewise, when predicting probabilities for investment-bearin } \\
\text { capacity, turnover is allowed to change. }\end{array}$} \\
\hline
\end{tabular}

